\title{
MOTIVASI INTERNAL PERAWAT DALAM MENERAPKAN SASARAN KESELAMATAN PASIEN (SKP) 5
}

\author{
Verily Endah Jati Wicaksana ${ }^{1}$, Meri Oktariani ${ }^{2}$, Dzurriyatun Thoyyibah $Z^{3}$ \\ ${ }^{1}$ Mahasiswa Program Studi Keperawatan Program Sarjana FakultasIlmu Kesehatan Universitas \\ Kusuma Husada Surakarta \\ ${ }^{2,3}$ Dosen Universitas Kusuma Husada Surakarta \\ e-mail: ${ }^{1}$ verily25@gmail.com, ${ }^{2}$ meri.oktariani81@gmail.com, ${ }^{3}$ thoyyibah.za@gmail.com
}

\begin{abstract}
Patient safety is a system where the hospital makes patient care safe. There are six goals for patient safety. Patient Safety Goal (PSGs) 5 is to reduce the risk of infection related to health services. An effort to eliminate the problem of infection by maintaining cleanliness through handwashing. One of the factors that influence nurses to implement PSGs 5 is internal motivation. The purpose of this study was to identify the relationship between the nurses' internal motivation and the implementation of Patient Safety Goals (PSGs) 5 in the inpatient room at Simo Hospital of Boyolali. This study used a descriptive correlative method with a cross-sectional study approach. A total sampling technique was applied to determine its samples consisted of 42 respondents. The data collection instruments were the internal motivation questionnaire and the patient safety goals (PSGs) 5 observation sheet. Its data were examined by using the Rank Spearman correlative test. The results showed a p-value of $0.000<0.05$. Therefore, Ho was rejected, Ha was accepted, and $r$ was 0.730. These results indicate a high relationship, have a positive and unidirectional correlation where the higher the internal motivation, the higher application of patient safety goals (PSGs) 5. This study infers that there is a relationship between nurses' internal motivation and the application of patient safety goals (PSGs) 5 in the inpatient room at Simo Hospital of Boyolali.
\end{abstract}

Keywords: Patient Safety; Patient Safety Goals (PSGs) 5; Internal Motivation

\begin{abstract}
ABSTRAK
Keselamatan pasien (patient safety) adalah suatu sistem dimana rumah sakit membuat asuhan pasien lebih aman. Keselamatan pasien terdapat enam sasaran keselamatan pasien. Sasaran Keselamatan Pasien (SKP) 5 yaitu mengurangi risiko infeksi tekait pelayanan kesehatan. Upaya menghilangkan masalah infeksi dengan cara menjaga kebersihan tangan melalui cuci tangan. Salah satu faktor yang mempengaruhi perawat untuk penerapan SKP 5 adalah motivasi internal. Tujuan penelitian ini untuk mengetahui adanya hubungan motivasi internal perawat dengan penerapan Sasaran Keselamatan Pasien (SKP) 5 di ruang rawat inap RSUD Simo Boyolali. Desain penelitian ini menggunakan metode deskriptif korelatif dengan pendekatan cross sectional study. Sampel pada penelitian ini berjumlah 42 responden, dengan teknik total sampling dan alat ukur kuesioner motivasi internal dan lembar observasi sasaran keselamatan pasien (SKP) 5. Uji yang digunakan yaitu uji korelatif Rank Spearman. Hasil penelitian menunjukkan bahwa $p$ value $0,000<0,05$ sehingga $\mathrm{H}_{\mathrm{o}}$ ditolak dan $\mathrm{H}_{\mathrm{a}}$ diterima dan hasil $\mathrm{r}$ yaitu sebesar 0,730 . Hal ini menandakan hubungan yang kuat yang mempunyai arah korelasi positif dan searah yaitu semakin tinggi motivasi internal maka semakin tinggi penerapan sasaran keselamatan pasien (SKP) 5. Kesimpulan penelitian ini adalah ada hubungan motivasi internal perawat dengan penerapan sasaran keselamatan pasien (SKP) 5 diruang rawat inap RSUD Simo Boyolali.
\end{abstract}

Kata Kunci : patient safety; sasaran keselamatan pasien (SKP) 5; motivasi internal 


\section{PENDAHULUAN}

Keselamatan pasien (patient safety) adalah suatu sistem dimana rumah sakit membuat asuhan pasien lebih aman. Sistem tersebut meliputi assessmen risiko, identifikasi dan pengelolaan hal yang berhubungan dengan risiko pasien, pelaporan dan analisis insiden, kemampuan belajar dari insiden dan tindak lanjutnya serta implementasi solusi untuk meminimalkan timbulnya risiko. Sistem tersebut diharapkan dapat mencegah terjadinya cedera yang disebabkan oleh kesalahan akibat melaksanakan suatu tindakan atau tidak melakukan tindakan yang seharusnya dilakukan ${ }^{1}$.

Menurut World Health Organization

(WHO) tahun 2017, keselamatan pasien (patient safety) merupakan masalah yang serius pada masyarakat global. Insiden keselamatan pasien yang dapat merugikan adalah $27 \%$ prosedur bedah; 18,3\% kesalahan pengobatan dan 12,2\% kesehatan infeksi terkait perawatan. Kesalahan medis tersebut disebabkan oleh faktor sistem dan faktor manusia ${ }^{2}$.

$\begin{array}{llr}\text { Keselamatan pasien } & \text { terdapat } & \text { enam } \\ \text { sasaran keselamatan } & \text { pasien } & \text { yaitu } \\ \text { mengidentifikasi pasien dengan } & \text { benar, } \\ \text { meningkatkan komunikasi yang efektif, }\end{array}$
meningkatkan keamanan obat-obat yang harus diwaspadai (high alert medications), memastikan lokasi dan prosedur pembedahan yang benar, mengurangi risiko infeksi tekait pelayanan kesehatan dan mengurangi risiko cedera pasien akibat terjatuh. Di Rumah Sakit pencegahan dan pengendalian infeksi merupakan sebuah tantangan. Kenaikan angka infeksi terkait pelayanan kesehatan menjadi keprihatinan bagi pasien dan petugas kesehatan. Upaya menghilangkan masalah infeksi yang terdapat dalam sasaran keselamatan pasien 5 dengan menjaga kebersihan tangan melalui cuci tangan ${ }^{3}$.

Menurut Budi (2019), terdapat berbagai variasi insiden berdasarkan sasaran keselamatan pasien. Pada Sasaran Keselamatan Pasien (SKP) 1 terdapat 14 variasi insiden $(31,88 \%, n=44)$ yaitu dengan tidak terpasangnya gelang identitas. Pada SKP 2 terdapat 8 variasi insiden $(7,97 \%, \mathrm{n}=11)$ dengan insiden terbanyak yaitu kesalahan komunikasi antara perawat dengan petugas laboratorium. Pada SKP 3 terdapat 14 variasi insiden $(41,30 \%, n=57)$ yaitu ketidaksesuaikan obat. Pada SKP 4 terdapat 3 variasi insiden $(2,90 \%, n=4)$ dengan insiden yang terjadi setelah operasi. Pada SKP 5 terdapat 1 variasi insiden $(1,45 \%, \mathrm{n}=2)$ yaitu phlebitis. Pada SKP 6 terdapat
6 variasi insiden $(13,04 \%, \mathrm{n}=18)$ dengan insiden pasien jatuh di kamar ${ }^{4}$.

Mencuci tangan menjadi salah satu langkah yang sangat efektif untuk mencegah terjadinya infeksi. Pencegahan melalui pengendalian infeksi di rumah sakit ini harus dilaksanakan oleh seluruh jajaran manajemen rumah sakit meliputi para dokter, bidan, perawat dan tenaga medis lainnya ${ }^{5}$.

Hasil penelitian yang dilakukan oleh Pambudi (2018), didapatkan bahwa jumlah tanggungan, lama bekerja, pengetahuan perawat, motivasi perawat, supervisi dan pengaruh organisasi mempengaruhi perawat dalam penerapan 6 SKP (Sasaran Keselamatan Pasien $)^{6}$.

Motivasi perawat berpengaruh positif terhadap keberhasilan program keselamatan pasien. Hasil ini membuktikan kebenaran teori motivasi internal (internal theory) yang menyatakan motivasi memberikan dorongan berbasis nilai, didorong oleh dorongan psikobiologis yang mengaktifkan dan menuntun perilaku manusia dalam menanggapi diri sendiri, lingkungan, kebutuhan yang dirasakan dan tujuan yang diinginkan ${ }^{7}$.

Motivasi perawat pelaksana jika ditinjau pada aspek yang dilihat dari prestasi, $31,1 \%$ perawat mengatakan kadang-kadang hasil kerjanya diperhatikan oleh rumah sakit, 57,8\% perawat mengatakan melaksanakan tugas sesuai dengan jadwal dan pedoman tepat waktu, $60 \%$ perawat mengatakan selalu menggunakan seluruh kemampuan keperawatan yang dimiliki. Jika dilihat dari jawaban perawat untuk pernyataan prestasi dimana perawat telah menggunakan kemampuannya dalam menerapkan keselamatan pasien, hal ini seharusnya menunjukkan bahwa perawat telah mencapai hasil yang baik dan berkualitas. Sedangkan pada pengembangan potensi diri, 44,4\% perawat menjawab atasan tidak pernah memberikan kesempatan untuk mengikuti pelatihan dan $53,3 \%$ perawat menjawab manajemen RS tidak memberikan kesempatan untuk meningkatkan kemampuan ${ }^{8}$.

Hasil studi pendahuluan didapatkan hasil perawat khususnya di ruang rawat inap belum maksimal dalam menerapkan five moment pada hand hygiene karena kurangnya motivasi internal setiap individu dalam hal tanggung jawab untuk menerapkan setiap hari, dimana standar yang ditetapkan WHO dalam hand hygiene adalah $100 \%$. Berdasarkan hasil wawancara dengan perawat PPI, didapatkan data bahwa pada bulan Oktober persentase hand hygiene 100\%. Pada bulan November didapatkan persentase 96\%. Dan 
pada bulan Desember mengalami penurunan dengan persentase yaitu $94 \%$. Maka motivasi atau dorongan dari dalam diri perawat sangat diperlukan untuk memaksimalkan penerapan pada SKP 5 yaitu mengurangi risiko infeksi dengan cara mencuci tangan.

\section{METODOLOGI PENELITIAN}

Penelitian ini dilakukan pada bulan Juli Agustus 2020. Pada penelitian ini menggunakan metode penelitian kuantitatif dengan menggunakan jenis penelitian deskriptif korelatif dan pendekatan cross sectional study Sampel pada penelitian ini sebanyak 42 responden diambil dengan teknik total sampling. Instrumen yang digunakan dalam penelitian ini adalah kuesioner motivasi internal dan lembar observasi SKP 5. Dalam penelitian ini uji statistik yang digunakan adalah uji Rank Spearman.

\section{HASIL DAN PEMBAHASAN}

Hasil yang didapatkan pada penelitian ini adalah: Tabel 4.1 Distribusi frekuensi karakteristik responden berdasarkan usia $(n=42)$

\begin{tabular}{lccc}
\hline $\begin{array}{c}\text { Karakteristik } \\
\text { Usia }\end{array}$ & Min & Max & Mean \\
\hline Usia & 24 & 50 & 33,67 \\
\hline
\end{tabular}

Berdasarkan tabel 4.1 Menunjukkan bahwa rata-rata usia responden adalah 34 tahun dengan usia terendah 24 tahun dan usia tertua adalah 50 tahun. Dalam penelitian Renggayuni (2016) mengatakan rata-rata usia perawat berada pada usia yang produktif yaitu antara 25-35 tahun dimana pada usia ini perawat dalam masa kedewasaan dan kematangan dalam mengaplikasikan semua kompetensi yang dimilikinya untuk menerapkan patient safety secara optimal' ${ }^{9}$. Seiring bertambahnya usia seseorang, perubahan dari segi fisik maupun psikologi akan terjadi. Bertambahnya usia juga bisa berpengaruh terhadap daya tangkap dan pola pikir seseorang dalam hal pengetahuan. Akan tetapi hal tersebut tidak lepas dari faktor lain juga yang mempengaruhi ${ }^{10}$.

Menurut pendapat peneliti, dengan teori dan hasil yang ada menunjukkan semakin bertambahnya usia dapat berpengaruh terhadap daya tangkap dan pola pikir seseorang dalam hal pengetahuan. Rata-rata usia produktif perawat yaitu 25-35 tahun.
Tabel 4.2 Distribusi frekuensi berdasarkan jenis kelamin $(n=42)$

\begin{tabular}{lcc}
\hline Jenis Kelamin & f & $\begin{array}{c}\text { Presentase } \\
(\%)\end{array}$ \\
\hline Perempuan & 36 & 85,7 \\
\hline Laki-laki & 6 & 14,3 \\
\hline Jumlah & $\mathbf{4 2}$ & $\mathbf{1 0 0}$ \\
\hline
\end{tabular}

Berdasarkan tabel 4.2 menunjukkan distribusi responden berdasarkan jenis kelamin diketahui bahwa mayoritas responden adalah berjenis kelamin perempuan sebanyak 36 responden $(85,7 \%)$. Dalam penelitian ini memiliki kesamaan dengan teori yang mengatakan bahwa jenis kelamin perempuan perawat mayoritas adalah perempuan, karena dalam sejarahnya keperawatan muncul sebagai peran care taking (pemberi perawatan) secara tradisional di dalam keluarga dan masyarakat ${ }^{11}$.

Menurut pendapat peneliti, dengan teori dan hasil yang didapatkan maka mayoritas responden perawat berjenis kelamin perempuan karena perempuan memiliki sifat mother instinct (keibuan) dan dalam sejarahnya keperawatan muncul sebagai peran care taking (pemberi perawatan) secara tradisional di dalam keluarga dan masyarakat.

Tabel 4.3 Distribusi frekuensi berdasarkan pendidikan $(\mathrm{n}=42)$

\begin{tabular}{lcc}
\hline Pendidikan & f & $\begin{array}{c}\text { Presentase } \\
(\mathbf{\%})\end{array}$ \\
\hline DIII & 37 & 88,1 \\
\hline DIV & 1 & 2,4 \\
\hline S1 & 1 & 2,4 \\
\hline Ners & 3 & 7,1 \\
\hline Jumlah & $\mathbf{4 2}$ & $\mathbf{1 0 0}$ \\
\hline
\end{tabular}

Berdasarkan tabel 4.3 menunjukkan distribusi responden berdasarkan pendidikan diketahui bahwa mayoritas responden adalah berpendidikan DIII sebanyak 37 responden $(88,1 \%)$.

Menurut Nursalam (2016), keperawatan diwajibkan untuk memiliki kemampuan dalam hal intelektual, interpersonal kemampuan teknis dan moral. Perawat yang melanjutkan pendidikan program ners dapat meningkatkan kualitas kerja perawat ${ }^{10}$.

Menurut pendapat peneliti, dengan teori dan hasil yang didapatkan bahwa mayoritas perawat lulusan DIII. Penerapan patient safety akan lebih 
baik jika latar belakang perawat berpendidikan $\mathrm{S} 1$ dan Ners.

Tabel 4.4 Distribusi frekuensi berdasarkan masa kerja $(\mathrm{n}=42)$

\begin{tabular}{cccc}
\hline \multirow{2}{*}{ Karakteristik } & \multicolumn{3}{c}{ Penilaian } \\
\cline { 2 - 4 } & Min & Max & Mean \\
\hline Masa Kerja & 1,6 & 15,11 & 6,2383 \\
\hline
\end{tabular}

Berdasarkan tabel 4.4 menunjukkan bahwa rata-rata masa kerja responden adalah 6 tahun dengan minimal masa kerja 1 tahun 6 bulan dan masa kerja maksimal adalah 15 tahun 11 bulan. Menurut Notoadmodjo (2012), semakin lama pengalaman kerja seseorang, makan akan semakin terampil, mudah memahami tugas dan memberi peluang dalam meningkatkan prestasi serta beradaptasi dengan lingkungan maka pengalaman yang diperoleh akan semakin baik ${ }^{12}$.

Menurut pendapat peneliti, dengan teori dan hasil yang didapatkan semakin lama pengalaman kerja perawat dapat memahami tugas dan terampil, meningkatkan pengetahuan dan dapat mempengaruhi kinerja dan tugasnya dalam penerapan keselamatan pasien.

Tabel 4.5 Distribusi frekuensi berdasarkan pendidikan $(\mathrm{n}=42)$

\begin{tabular}{ccc}
\hline $\begin{array}{c}\text { Pelatihan } \\
\text { patient safety }\end{array}$ & f & $\begin{array}{c}\text { Persentase } \\
(\mathbf{\%})\end{array}$ \\
\hline Pernah & 36 & 85,7 \\
\hline Tidak Pernah & 6 & 14,3 \\
\hline Total & $\mathbf{4 2}$ & $\mathbf{1 0 0}$ \\
\hline
\end{tabular}

Berdasarkan tabel 4.5 menunjukkan distribusi responden berdasarkan pelatihan patient safety diketahui bahwa mayoritas responden adalah pernah mengikuti pelatihan patient safety sebanyak 36 responden (85,7\%). Dalam penelitian Qalbia (2013) mengatakan bahwa perawat yang pernah mengikuti pelatihan patient safety sebanyak 58 orang $(90,6 \%)$ dan yang belum pernah mengikuti sebanyak 6 orang $(9,4 \%)^{13}$. Menurut penelitian Yulia, Hamid dan Mustikasari (2012) mengatakan bahwa pelatihan berpengaruh terhadap pemahaman perawat dalam penerapan keselamatan pasien ${ }^{14}$.

Berdasarkan pembahasan diatas peneliti mengambil keputusan bahwa pentingnya perawat mengikuti pelatihan patient safety guna perawat bisa menerapkan sasaran keselamatan pasien dengan baik.
Tabel 4.6 Distribusi frekuensi motivasi internal perawat di ruang rawat inap RSUD Simo Boyolali $(\mathrm{n}=42)$

\begin{tabular}{ccc}
\hline $\begin{array}{c}\text { Motivasi internal } \\
\text { perawat }\end{array}$ & f & $\begin{array}{c}\text { Persentase } \\
(\%)\end{array}$ \\
\hline Tinggi & 36 & 85,7 \\
Sedang & 6 & 14,3 \\
Rendah & - & - \\
\hline Total & $\mathbf{4 2}$ & $\mathbf{1 0 0}$ \\
\hline
\end{tabular}

Berdasarkan tabel 4.6 menunjukkan distribusi responden berdasarkan motivasi internal perawat di ruang rawat inap RSUD Simo Boyolali diketahui bahwa mayoritas responden mempunyai motivasi internal perawat tinggi sebanyak 36 responden $(85,7 \%)$.

Menurut teori Nursalam (2015), motivasi internal adalah motivasi yang berasal dari dalam diri orang tersebut, yang mendorong dirinya menjadi produktif ${ }^{10}$. Motivasi dapat menunjukkan sejauh mana seseorang bisa berusaha untuk mendapatkan kinerja yang baik di pekerjaan. Perawat dengan motivasi tinggi maka sikap perawat akan mendukung dalam penerapan program patient safety akan semakin tinggi juga ${ }^{15}$.

Menurut pendapat peneliti, dengan teori dan hasil yang didapatkan bahwa motivasi dapat mendorong untuk melakukan sesuatu. Motivasi internal memiliki beberapa indikator. Perawat dengan motivasi tinggi maka sikap perawat akan mendukung dalam penerapan program patient safety akan semakin tinggi juga.

Tabel 4.7 Distribusi frekuensi pelaksanaan Sasaran Keselamatan Pasien (SKP) 5 di ruang rawat inap RSUD Simo Boyolali $(n=42)$

\begin{tabular}{ccc}
\hline $\begin{array}{c}\text { Pelaksanaan } \\
\text { SKP 5 }\end{array}$ & f & $\begin{array}{c}\text { Persentase } \\
(\boldsymbol{\%})\end{array}$ \\
\hline Baik & 32 & 76,2 \\
Cukup & 10 & 23,8 \\
Kurang & - & - \\
\hline Total & $\mathbf{4 2}$ & $\mathbf{1 0 0}$ \\
\hline
\end{tabular}

Berdasarkan tabel 4.7 menunjukkan distribusi responden pelaksanaan sasaran keselamatan pasien (SKP) 5 di ruang rawat inap RSUD Simo Boyolali diketahui bahwa mayoritas responden melaksanakan sasaran keselamatan pasien (SKP) dengan baik sebanyak 32 responden $(76,2 \%)$. Dalam penelitian Lombogia (2016) menunjukkan bahwa kemampuan perawat dalam penerapan patient safety pada pengurangan resiko infeksi yang baik sebanyak 21 orang dengan hasil 
$(67,7 \%)$ dan kurang baik sebanyak 10 orang dengan hasil $(32,3 \%)^{16}$.

Di Indonesia menerapkan sasaran keselamatan pasien ke 5 (pengurangan risiko infeksi terkait pelayanan kesehatan) dengan kebijakan tentang pencegahan infeksi, pedoman kebersihan tangan (hand hygiene) menurut standar WHO dan rumah sakit melaksanakan program hand hygiene3.

Berdasarkan pembahasan diatas peneliti mengambil keputusan bahwa sebagian besar perawat belum sepenuhnya menerapkan patient safety sesuai standar SNARS dalam pengurangan resiko infeksi.

Tabel 4.8 Hasil hubungan motivasi internal dengan penerapan sasaran keselamatan pasien (SKP) 5

\begin{tabular}{ccc}
\hline Variabel & $\boldsymbol{r}$ & $\boldsymbol{p}$-value \\
\hline Motivasi internal & 0,730 & 0,000 \\
dengan penerapan & & \\
sasaran & & \\
keselamatan pasien & & \\
(SKP) 5 & & \\
\hline
\end{tabular}

Berdasarkan Tabel 4.8 menunjukkan bahwa hasil uji nilai $p$-value sebesar $0,000<\alpha(0,05)$ maka hal ini berarti Ho ditolak atau Ha diterima, yang berarti ada hubungan motivasi internal dengan penerapan sasaran keselamatan pasien (SKP) 5 di ruang rawat inap RSUD Simo Boyolali. Hasil $r$ yaitu sebesar 0,730. Hal ini menandakan hubungan yang kuat yang mempunyai arah korelasi positif dan searah yaitu semakin tinggi motivasi internal maka semakin tinggi penerapan sasaran keselamatan pasien (SKP) 5 .

Dalam penelitian Ritonga (2020) menujukkan bahwa hubungan karakteristik responden yaitu jenis kelamin $p=0,354>0,05$ dengan arti tidak ada hubungan jenis kelamin dengan motivasi perawat dalam penerapan keselamatan pasien. Karakteristik umur responden menunjukkan $p=$ $0,000<0,05$ dengan arti ada hubungan antara hubungan umur perawat dengan motivasi perawat dalam penerapan keselamatan pasien. Karakteristik pendidikan perawat yaitu $\mathrm{p}=0,001$ $<0,05$ dengan arti ada hubungan pendidikan perawat dengan motivasi perawat dalam penerapan keselamatan pasien. Masa kerja perawat $p=0,001<0,05$ dengan arti ada hubungan masa kerja perawat dengan motivasi perawat dalam penerapan keselamatan pasien ${ }^{15}$.

Dilihat dari aspek pernyataan prestasi, perawat telah menggunakan kemampuannya untuk menerapkan patient safety dan seharusnya perawat telah mencapai hasil yang baik dan berkualitas. Dalam aspek pengembangan potensi diri $44,4 \%$ perawat mengatakan tidak pernah memberikan kesempatan untuk mengikuti pelatihan dan $53,3 \%$ perawat mengatakan manajemen RS tidak memberikan kesempatan untuk meningkatkan kemampuan ${ }^{17}$.

Berdasarkan pembahasan diatas peneliti mengambil kesimpulan bahwa motivasi internal pada perawat berpengaruh terhadap penerapan sasaran keselamatan pasien. Perawat dengan motivasi tinggi maka sikap perawat dalam mendukung penerapan patient safety akan semakin tinggi juga dan bisa mencapai kinerja yang baik di pekerjaan.

\section{KESIMPULAN DAN SARAN}

Hasil penelitian yang telah dilakukan dapat disimpulkan bahwa terdapat hubungan motivasi internal perawat dengan penerapan sasaran keselamatan pasien (SKP) 5 di ruang rawat inap RSUD Simo Boyolali dengan $p$-value 0,000. Hasil $r$ yaitu sebesar 0,730. Hal ini menandakan hubungan yang kuat yang mempunyai arah korelasi positif dan searah yaitu semakin tinggi motivasi internal maka semakin tinggi penerapan sasaran keselamatan pasien (SKP) 5.

Saran dari penelitian ini diharapkan bisa memberikan informasi, pengetahuan dan literatur kepada peneliti selanjutnya untuk mengembangkan penelitian ini dengan variabel independen yang berbeda dan lebih banyak, dengan judul faktor-faktor yang berhubungan dengan penerapan sasaran keselamatan pasien (SKP) 5 di ruang rawat inap RSUD Simo Boyolali.

\section{DAFTAR PUSTAKA}

1. Kementerian Kesehatan RI. National Guideliness for Hospital Patient Safety. 2015

2. WHO. Monitoring health for the SDGs. World Health Statistics. 2017

3. SNARS. Panduan Standar Nasional Akreditasi Rumah Sakit. Jakarta : Tim SNARS. 2018

4. Budi, S.C., Nurdini, A., Sunartini, L., Lazuardi, F.S. Tetra. Keakuratan rekam medis berdasarkan laporan insiden pasien jatuh di rumah sakit. Prosiding seminar manajemen informasi kesehatan nasional (SMIKNAS). Surakarta. 2019 
5. Septiari, B.B. Infeksi Nosokomial. Yogyakarta : Nuha Medika. 2012

6. Pambudi, Y.D.W., Sutriningsih, A., Yasin, D.D.F. Faktor-Faktor Yang Mmepengaruhi Perawat pada Penerapan 6 SKP (Sasaran Keselamatan Pasien) pada akreditasi JCI (Joint Commission International) di ruang rawat inap RS Panti Waluya Malang. Nursing News. Jurnal Ilmiah Keperawatan vol 3. no. 1. 2018

7. Yenny. Pengaruh Kompetensi, Motivasi, dan Disiplin Kerja Terhadap Kinerja Guru pada Yayasan Pendidikan imanuel Palu. E-Jurnal Katalogis. 6(2). 2018

8. Morika, H. D. Jurnal Kesehatan Medika Saintika. Motivasi Dengan Kinerja Perawat Pelaksana Dalam Menerapkan Keselamatan Pasien. 2016

9. Renggayuni, A. Motivasi eksternal perawat dalam menerapkan patient safety. Online Journal Unsyiah. www.jim.unsyiah.ac.id/FKep/article/vie w/1486. 2016

10. Nursalam. Konsep dan Penerapan Metodologi Penelitian Ilmu Keperawatan: Pedoman Skripsi, Tesis dan Instrumen. Edisi 2. Jakarta : Salemba Medika. 2015

11. Rollinson, D. \& Kish. Care concept in advanced nursing. St.Louis Mosby A Harcourt Health Science Company. 2010
12. Notoatmodjo, S. Promosi Kesehatan Teori dan Aplikasi. Jakarta : Rineka Cipta. 2012

13. Qalbia. Hubungan Motivasi dan supervisi terhadap kinerja perawat pelaksana dalam menerapkan patient safety di rawat inap RS Universitas Hasanuddin. Makassar. 2013

14. Yulia, S., Hamid, A.Y.S., Mustikasari. Peningkatan Pemahaman Perawat Pelaksana Dalam Penerapan Keselamatan Pasien Melalui Pelatihan Keselamatan Pasien. Jurnal Keperawatan Indonesia. Vol. 15. no. 3.2012

15. Ritonga, E.P. Hubungan Karakteristik dan Motivasi Perawat dalam Penerapan Keselamatan Pasien di Ruang Rawat Inap Rumah Sakit Umum Imelda Pekerja Indonesia Medan. Indonesian Trust Health Journal Volume 3, No. 1. 2020.

16. Lombogia, A. Hubungan Perilaku dengan Kemampuan Perawat dalam Melaksanakan Keselamatan Pasien (Patient Safety) di Ruang Akut Instalasi Gawat Darurat RSUP Prof. Dr. R.D. Kandou Manado. E-jurnal Keperawatan. Vol 4. no. 2. 2016

17. Rhona Sandra. Hubungan Spritual dengan tingkat kecemasan pada pasie pre operasi. Jurnal Kesehatan Medika Saintika, 9(1), 24-33. 2015 